\title{
Media-Media Pembelajaran Efektif dalam Membantu Pembelajaran Matematika Jarak Jauh
}

\author{
Dewasni Hasiru1*, Syamsu Qamar Badu², Hamza B. Uno ${ }^{3}$
}

\author{
1,2,3 Jurusan Matematika, Fakultas MIPA, Universitas Negeri Gorontalo, \\ Jl. Prof. Dr. Ing. B. J. Habibie, Tilongkabila, Kabupaten Bone Bolango, Gorontalo 96119, Indonesia
}

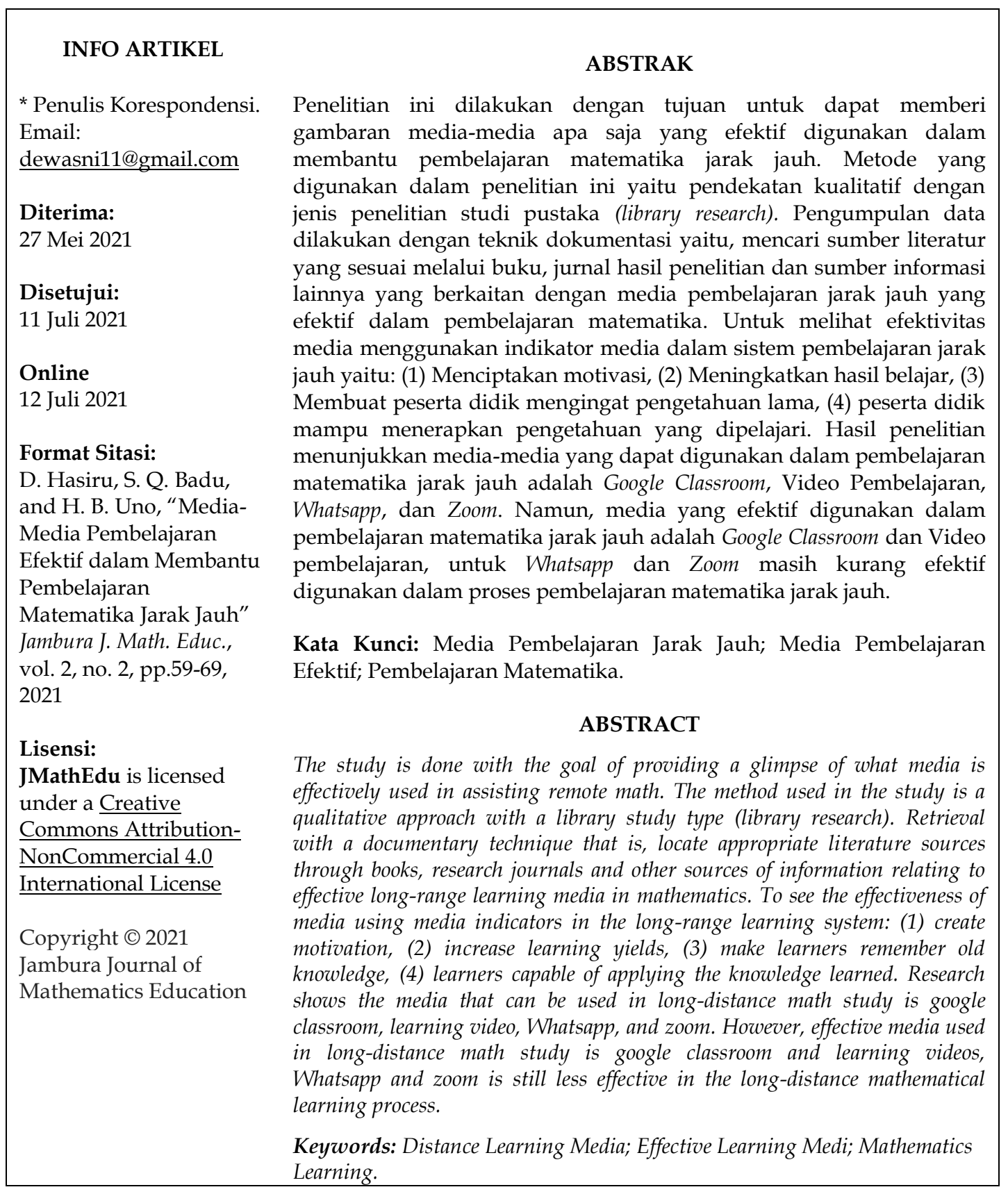




\section{Pendahuluan}

Awal tahun 2020 dunia digemparkan dengan menyebar luas jenis virus baru yaitu coronavirus (sars-cov2) yang berasal dari China. Virus ini masuk ke Indonesia pada bulan maret 2020 [1]. Kasus covid 2019 di Indonesia setiap harinya melonjak sehingga saat ini pemerintah berupaya memutus rantai penyebaranya dengan membatasi interaksi masyarakat salah satunya dengan menerapkan pembelajaran jarak jauh. Semua kegiatan belajar mengajar dilakukan dari rumah termasuk mata pelajaran matematika. Pembelajaran matematika dimaknai sebagai suatu pembelajaran yang dapat mewujudkan harapan pelajar agar dapat bersaing di era globalisasi. Tentunya ini dapat diwujudkan melalui hal yang paling sederhana yaitu dengan mendapat hasil belajar yang memuaskan.

Permasalahan saat ini banyak peserta didik menganggap metematika itu sulit. Tak sedikit yang menganggap bahwa matematika adalah sebuah momok yang harus dihindari. Matematika dianggap sebagai pembelajaran yang sulit karena karakteristik metamatika bersifat abstrak, logis sistematis dan penuh dengan lambang serta rumus yang membingungkan [2]. Kesulitan yang ada dalam pembelajaran matematika menuntut kreatifitas guru mata pelajaran untuk mengembangkan pelajaran baik dalam hal metode maupun media yang digunakan.

Penggunaan media online dapat menjadi solusi pembelajaran jarak jauh. Pembelajaran yang dilakukan secara online tentunya menguak sejumlah problem tersendiri. Tidak dapat dipungkiri dengan adanya suasana pembelajaran baru tentunya tidak begitu saja dapat beradaptasi dengan baik. Banyak sekali kendala-kendala yang dihadapi oleh pendidik dan peserta didik dalam proses pembelajaran jarak jauh. Kendala paling umum yaitu kondisi signal yang tidak mendukung saat pembelajaran daring (online), tidak semua peserta didik memiliki fasilitas untuk belajar daring sehingga pembelajaran menjadi tidak efektif, peserta didik menjadi setres karena kurang motivasi dalam belajar jarak jauh, lebih banyak penugasan yang membuat peserta didik menjadi stres. Situasi seperti ini dibutuhkan juga peran yang besar dari orang tua untuk dapat sama-sama memberikan dukungan serta membantu para peserta didik sebagai mediator di rumah. Dalam hal ini peran media pembelajaran sangat dibutuhkan untuk dapat menjadi wadah atau perantara sehingga pembelajaran jarak jauh menjadi efektif. Seperti yang dikemukakan oleh Susilana dan Cepy [3] bahwa media pembelajaran merupakan wadah atau tempat dari sebuah pesan, pesan yang disampaikan adalah materi dan pesan pembelajaran, serta tujuan yang ingin dicapai adalah ialah proses pembelajaran. Penggunaan media secara inovatif dan kreatif akan menambah lebih banyak pengetahuan bagi peserta didik sehingga dapat belajar lebih banyak, apa yang mereka pelajari akan lebih baik, dan meningkatkan penampilan dalam melakukan keterampilan sesui dengan apa yang menjadi tujuan pembelajaran.

Media pembelajaran digunakan untuk menyalurkan pesan berupa pikiran, perasaan, dan perhatian yang sangat berguna dalam pembelajaran. Media juga dapat membantu mengajarkan konsep-konsep abstrak sehingga akan lebih mudah diterima oleh peserta didik. Dalam pembelajran sebagai proses interaksi antara siswa dengan guru dan sumber belajar lainya perlu didukung penggunaan media yang tepat. Ada begitu banyak media pembelajaran yang dapat membantu proses pembelajaran. Beberapa penelitian mengenai media pembelajaran menunjukkan bahwa terdapat banyak media yang dapat menjadi alternatif pembelajaran jarak jauh seperti video pembelajaran [4], 
pemanfaatan e-learning [5], media e-learning berbasis whatssap [6], media pembelajaran berbantuan Edmodo [7], pembelajaran berbasis Web [8], termasuk media pembelajaran online seperti google classroom [9] dimana peranan media baru di sector pendidikan ini menghasilkan proses yang begitu mudah dilakukan serta dapat mendorong pelajar untuk belajar lebih banyak tentang literasi internet. Hal ini sangat sesui dengan perkembangan serta kemajuan di era saat ini. Selain itu terdapat juga media pembelajaran online yang dapat secara tidak langsung menggantikan fungsi dari pembelajaran tatap muka yaitu penggunaan zoom sebagai alternatif video converencing yang membuat pembelajaran lebih efektif serta menciptakan pembelajaran yang lebih fleksibel saat penggunaanya [10].

Berdasarkan beberapa media yang terdapat dalam hasil penelitian tersebut penggunaanya hanya secara umum untuk mata pelajaran apapun. Namun, dalam pembelajaran matematika yang memiliki karakeristik tersendiri media yang tepat untuk dijadikan alternatif media yang efektif begitu beragam. Sehingga sebagai seorang guru serta orang tua harus dapat mengindetifikasi berbagai jenis media yang ada dan memilih media yang efektif serta cocok digunakan untuk mendukung kegiatan pembelajaran. Oleh karena itu, perlu dilakukan kajian terkait media-media yang efektif dalam membantu pembelajaran jarak jauh.

\section{Metode}

Jenis penelitian yang digunakan dalam penelitian ini adalah studi pustaka (library research) dengan pendekatan kualitatif yaitu penelitian yang mengumpulkan data dengan mengkaji literatur-literatur sebelumnya atau karya tulis ilmiah sebagai sumber data utama. Dengan maksud untuk menggali teori dan konsep yang telah ada sebelumnya, dengan mengikuti perkembangan penelitian pada bidang yang akan diteliti. Dalam penelitian ini literatur yang dikaji relevan dengan media-media pembelajaran yang efektif dalam pembelajaran matematika untuk memperoleh data mengenai media apasaja yang dapat digunakan dalam pembelajaran matematika yang kemudian dianalis untuk memperoleh media yang efektif digunakan dalam pembelajaran matematika.

Data yang diolah dalam penelitian ini adalah berupa data yang ditemukan dari sejumlah literatur buku maupun jurnal-jurnal hasil penelitian sebelumnya dan sumber informasi lainya yang relevan dengan media-media pembelajaran yang efektif dalam pembelajaran matematika.

Pengumpulan data yang digunakan dalam penelitian ini adalah teknik dokumentasi, yaitu mencari dan menemukan data melalui literatur buku, jurnal hasil penelitian, skripsi, dan sumber-sumber informasi lainnya yang relevan dengan topik penelitian. Untuk mendapatkan data dapat dilakukan dengan lengkah-langkah sebagai berikut: Mencari bahan bacaan yang relevan dengan media pembelajaran jarak jauh dalam pembelajaran matematika. Kemudian Membaca, mencatat, menganalisis dan menghubungkan data-data yang diperoleh. Setelah data terkumpul disajikan dalam bentuk uraian yang telah dianalisis, dikembangkan dan dihubungkan satu sama lain sehingga manejadi sebuah riset yang baru. Untuk memperoleh data mengenai media yang efektif di fokuskan pada jurnal-jurnal hasil penelitian sebelumnya dengan teknik pemilihan jurnal berdasarkan indikator media yang memenuhi kriteria efektif yaitu: (1) Menciptakan motivasi belajar, (2) Meningkatkan hasil belajar, (3) Membuat peserta 
D. Hasiru, dkk | Media-Media Pembelajaran Efektif dalam Membantu Pembelajaran ...

didik mengingat pengetahuan lama, (4) Peserta didik mampu menerapkan pengetahuan yang dipelajari.

Teknik analisis Dalam membahas dan menelaah data, peneliti menggunakan metode deskriptif analitis untuk menyusun, serta menafsirkan data yang sudah ada. Selain itu metode ini digunakan untuk menguraikan secara lengkap, teratur dan teliti terhadap suatu obyek penelitian.

\section{Hasil dan Pembahasan}

Terdapat beragam media pembelajaran yang dapat digunakan dalam pembelajaran jarak jauh. Dalam penggunaan media pembelajaran terdapat banyak aspek yang harus diperhatikan sebelum menggunakan media tersebut dalam proses pembelajaran. berdasarkan temuan dari literature yang relevan berikut beberapa media yang dapat digunakan dalam pembelajaran jarak jauh serta efektifitasnya dalam pembelajaran matematika.

\subsection{Identifikasi media-media yang efektif dalam membantu pembelajaran matematika jarak jauh}

Untuk mengetahui media-media yang dapat digunakan dalam membantu pembelajaran matematika jarak jauh perlu mengetahui media-media pembelajaran jarak jauh apasaja yang banyak digunkan dalam proses pembelajaran matematika halhal yang perlu di analisis adalah efektifitas media yang digunakan, kualitas mediamedia tersebut, serta media mana yang paling dominan digunakan dalam pembelajaran matematika jarak jauh. Mengidentifikasi media-media berdasarkan analisis hasil penelitian sebelumnya yang relevan:

Pada penelitian Mustakim [11] disebutkan bahwa media yang dapat digunakan dalam pembelajaran matematika jarak jauh adalah media online dalam penelitian ini media yang digunakan adalah google classroom, whatsapp group, youtube, instagram, dan zoom. Hasil penelitian menunjukan penggunaan media online dalam pembelajaran matematika jarak jauh efektif. Selanjutnya, Muthy dan Pujiastuti [12] mengungkapkan bahwa media yang dapat digunakan adalah media yang e-learning dalam hal ini media tersebut adalah whatsapp dan google classroom. Penggunaan media e-learning dengan memanfaatkan teknologi efektif karena dapat memenuhi prinsip dan pertimbanagan memilih media yang dikenal dengan istilah ACTION (Access, Cost, Technology, Interactivity, Organization, Novelety). Dalam penelitian yang dilakukan oleh Wijaya [13] dijelaskan bahwa media pembelajaran yang banyak digunakan dan menjadi rekomendasi untuk digunakan dalam pembelajaran matematika jarak jauh adalah video pembelajaran dapat dilihat bahawa di Negara China video pembelajaran dapat menjadi media yang efektif digunakan dalam pembelajaran matematika jarak jauh. Hal serupa diungkapkan oleh Husna [14] bahwa media pembelajaran yang dapat digunakan dalam pembelajaran matemaatika jarak jauh adalah media M-Learning. Media M-Learning dapat menjadi alternatif media yang efektif digunakan dalam membantu pembelajaran matematika jarak jauh karena dapat mempengaruhi hasil belajar menjadi lebih baik atau lebih tinggi dibandingkan dengan hasil belajar tanpa menggunakan media tersebut. Lebih lanjut, Apsari, dkk [15] mengemukakan bahwa media yang dapat menjadi alternatif membantu pembelajan matematika jarak jauh adalah media obrolan multi arah dalam hal ini media yang digunakan adalah chat group. Penggunaan media multiarah dapat menjadi media pembelajran yang 
membantu pemebelajaran matematika jarak jauh karena dapat membantu pelajar untuk aktif serta memperoleh hasil belajar yang optimal.

Berdasarkan beberapa hasil penelitian diatas, media yang terbukti efektif dan dominan digunakan dalam membantu pembelajaran matematika jarak jauh secara umum adalah media-media yang berbasis internet dan teknologi. Secara spesifik media-media tersebut adalah Google Classroom, Video Pembelajaran, Whatsapp dan Zoom.

\subsection{Efektifitas masing-masing media yang telah teridentifikasi dapat digunakan dalam membantu pembelajaran matematika jarak jauh}

Untuk melihat dan mengetahui efektifitas sebuah media, digunakan indikator media pembelajaran dalam sistem pembelajaran jarak jauh yang efektif yaitu: menciptakan motivasi belajar, meningkatkan hasil belajar, membuat peserta didik mengingat pengetahuan lama, memungkinkan peserta didik mampu menerapkan pengetahuan yang dipelajari. Perlu diketahui juga kekuraangan dan kelebihan dari media-media tersebut [16].

\section{Google Calassroom}

Google Classroom merupakan media pembelajaran yang dikembangkan oleh google untuk sekolah online yang bertujuan menyederhanakan pembuatan, pendistribusian serta penetapan tugas tanpa menggunakan kertas lagi. Penggunaan google classroom dapat menambah pengetahuan baru yang sejalan dengan perkembangan teknologi di era digital karena google classroom mampu menciptakan peluang bagi pelajar maupun pengajar untuk dapat mengembangkan lebih banyak literasi dan kompetisi dibidang IT.

Berdasarkan analisis beberapa penelitian, media google classroom dapat menjadi alternatife media pembelajaran yang efektif digunakan dalam membantu pembelajaran matematika jarak jauh. Hal ini dibuktikan dengan temuan penelitian oleh Mudamayanti [17] yang menyebutkan bahwa penggunaan media google classroom dapat membantu proses pembelajaran lebih efektif karena memberi pengaruh positif terhadap hasil belajar dimana nilai rata-rata hasil belajar yang menggunakan google classroom lebih besar daripada yang tidak menggunakan google classroom. Selanjutnya, Darmawan [18] menemukan bahwa penggunaan media google classroom dalam pembelajaran matematika dapat meningkatkan hasil belajar. Dengan demikian, berdasarkan kedua temuan tersebut google classroom dapat memenuhi salah satu indikator media yang efektif digunakan dalam pembelajaran matematika jarak jauh.

\section{Video Pembelajaran}

Video pembelajaran merupakan sebuah media yang memanfaatkan suara dan gambar secara bersamaan yang efektif digunakan dalam pembelajaran karena merupakan media yang kongkret dalam menyampaikan suatu informasi, membentuk opini dan menarik empati masyarakat yang dirancang secara khusus untuk digunakan dalam kegiatan pembelajaran seperti merangsang sikap, menayangkan sesuatu, tempat secara virtual dan realistik, meningkatkan pengetahuan, melatih keterampilan, dan sebagainya sehingga dapat dikatakan mampu membelajarkan berbagai jenis topik pembelajaran baik yang bersifat khognitif, afektif dan psikomotorik. Dalam memilih dan menggunakan video pembelajaran dapat dilakukan dengan dua cara yaitu mengevaluasi dan mengembangkan media yang sudah tersedia dan memproduksi 
video pembelajaran sesui kebutuhan pembelajaran. Terdapat beberapa situs web yang menyediakan video pembelajaran yaitu Youtube, Tv Edukasi, Linkkedin Learning, Microsoft Education Center, Ruang Guru, Quipper, Zenius, Coursera [19]. Untuk video pembelajaran yang perlu dirancang hal-hal yang perlu perhatikan adalah aspek konten, durasi video, bentuk media video, penggunaan warna, musik dan ilustrasi, presenter, penggunaan bahasa, dan penugasan melalui video [20].

Hasil analisis penelitian sebelumnya video pembelajaran dapat menjadi alternatif media yang efektif dalam membantu pembelajaran matematika jarak jauh. Hal ini dibuktikan berdasarkan temuan penelitian Krisna dan Marga [21] yang menunjukan bahwa penggunaan video dalam pembelajaran matematika cukup efektif digunakan dalam kelas virtual. Selain itu dengan menggunakan video siswa dapat memahami pembelajaran dengan baik karena keunggulan video yang dapat di puse dan diulangulang. Hal ini sejalan dengan temuan Nurdin, dkk [22] yang menunjukan bahwa video pembelajaran yang berbasis geogebra dapat menjadi salah satu alternatif media pembelajaran yang variatif, efektif dan efisien karena terbukti ampuh untuk meningkatkan kemampuan pemahaman konsep matematis siswa. Lebih lanjut, Baharuddin [23] menunjukan bahwa video tutorial dapat menjadi alternatif media yang dapat digunakan dalam pembelajaran matematika jarak jauh dibuktikan dengan adanya perbedaan rata-rata minat peserta didiksebelum dan sesudah menerapkan video tutorial. Berdasarkan temuan dari berberapa penelitian tersebut video pembelajaran memenuhi indikator media yang efektif digunakan dalam pembelajaran jarak jauh yaitu membuat peserta didik mengingat pengetahuan lebih lama, meningkatkan pemahaman konsep serta minat dalam belajar.

\section{Whatsapp}

Whatsapp adalah media komunikasi yang juga dapat digunakan dalam membantu pembelajaran jarak jauh sebagai media komunikasi digital yang mencakup pesan berupa teks, gambar, video audio dan juga dapat digunakan untuk menelpon sehingga menjadi satu paket yang lengkap dalam membantu untuk menjamin komunikasi di seluruh dunia. Penggunaan whatsapp dalam pembelajaran [24] yaitu, dapat memberi fasilitas pembelajaran secara online antara guru dan siswa baik di rumah maupun di sekolah, menjadi aplikasi online yang mudah dan hemat di gunakan, dapat digunakan untuk berbagi (komentar, tulisan, gambar, video, suara dan dokumen), memberikan kemudahan membagi informasi berupa pengumuman maupun membagikan karya dalam group, dapat berbagi fitur sehingga dapat dengan mudah menyebarkn informasi dan pengetahuan.

Berdasarkan hasil penelitian Yensy [25], ditunjukkan bahwa penggunaan whatsapp cukup efektif digunakan dalam membantu pembelajaran matematika dilihat dari hasil belajar sebelum dan sesudah penggunaan media whatsapp. Namun demikian, Kiayimodjo [26] mengungkap bahwa penggunaan media whatsapp dalam membantu pembelajaran matematika jarak jauh berdasarkan hasil belajar berada dalam kategori kurang. Hal ini menunjukkan bahwa media whatsapp belum cukup efektif digunakan dalam membantu pembelajaran matematika jarak jauh karena belum dapat memenuhi kriteria dari salah satu indikator media yang efektif digunakan dalam pembelajaran jarak jauh.

Dalam penggunaanya whatsapp dapat digunakan dalam pembelajaran jarak jauh perlu memperhatikan beberapa hal yaitu perumusan tujuan yang jelas, pengenalan materi 
pelajaran, adanya kemudahan materi sehingga siswa mudah untuk mempelajarinya, memberikan tugas yang mudah disertai dengan perintah dan arahan yang jelas, materi pembelajaran yang disampaikan dengan tingkat perkembangan masing-masing siswa, materi pembelajaran disampaikan dengan sistematis dan mampu memberikan motivasi belajar, materi disampaikan dengan kenyataan, sehingga siswa dengan mudah dapat memahami menyerap dan mempraktekkannya, metode yang digunakan harus efektif jelas dan mudah dipahami oleh siswa serta disetai dengan contoh, ilustrasi, video, demonstrasi, dan lainya.

\section{Zoom}

Zoom merupakan sebuah media yang menjadi alternatife dalam membantu pembelajaran jarak jauh yang berbasis online berupa video converencing. Karakteristik pembelajaran matematika yang abstrak yang begitu sukar diajarkan dan butuh penjelasan lebih sehingga membutuhkan media zoom. Berdasarkan hasil penelitian Kusumah dan Hamidah [27] yang melakukan perbandingan media whatsapp dan media zoom terlihat bahwa penggunaan zoom lebih baik dalam meningkatkan hasil belajar dalam pembelajaran matematika jarak jauh. berdasarkan analisis referensi media zoom belum cukup efektif digunakan dalam membantu pembelajaran matematika jarak jauh. Hal ini dikarenakan minimnya literatur sehingga untuk aplikasi zoom belum dapat secara spesifik ditemukan memenuhi salah satu indikatir media yang efektif digunakan dalam pembelajaran jarak jauh.

\subsection{Kekurangan dan Kelebihan Media}

Dalam penggunaan media pembelajaran terdapat kelebihan dan kekurangan pada masing-masing media yang digunakan. Kekurangan dan kelebihan media dapat menjadi pertimbangan dalam memilih dan menggunakan media yang tepat pada setiap proses pembelajaran. Hasil analisis dari sumber-sumber yang relevan terdapat beberapa kelebihan dan kekurangan media Google Classroom, Video pembelajaran, Whastapp dan Zoom. Keterangan lebih lengkap disajikan pada Tabel 1 s.d Tabel 4.

Table 1. Kelebihan dan kekurangan media google classroom

Kelebihan Kekurangan

Mudah digunakan melalui komputer HP Sedikit mempersulit pemula karena akan maupun tablets menemukan beberapa simbol google di dalamnya bahkan file Word harus dikonversi ke Google Doc terlebih dahulu

Efektif digunakan dalam berkomunikasi Tidak terdapat update otomatis mengenai dan menyalurkan berbagai materi tugas maupun informasi

Menghemat waktu dalam pengumpulan tugas

Meningkatkan kerja sama antar pelajar dan komunikasi yang lebih baik

Lebih hemat karena tidak menggunakan kertas

Ramah dan aman

Sulitnya pembelajar untuk berbagi tugas mereka kepada teman lain

Pembelajar dapat memanipulasi dengan mengubah soal yang telah diberikan

Tidak ada kuis atau tes otomatis

Belum tersedianya chat live

Mempunyai sistem komen yang menarik 
D. Hasiru, dkk | Media-Media Pembelajaran Efektif dalam Membantu Pembelajaran ...

\begin{tabular}{l}
\hline $\begin{array}{l}\text { untuk semua orang, pengajar dan } \\
\text { pembelajaran }\end{array}$ \\
\hline
\end{tabular}

Table 2. Kelebihan dan kekurangan media video pembelajaran

\begin{tabular}{lll}
\hline \multicolumn{2}{c}{ Kelebihan } & \multicolumn{1}{c}{ Kekurangan } \\
\hline $\begin{array}{l}\text { Banyak variasi video pembelajaran yang } \\
\text { dapat dirancang sendiri oleh guru }\end{array}$ & $\begin{array}{l}\text { Memerlukan banyak kuota internet untuk } \\
\text { mendownload video terutama yang } \\
\text { berukuran besar }\end{array}$ \\
$\begin{array}{l}\text { Menciptakan suasana yang tidak } \\
\text { membosankan }\end{array}$ & $\begin{array}{l}\text { Video pembelajaran tidak interaktif } \\
\text { karena pembelajar tidak dapat secara } \\
\text { langsung menanyakan jika ada materi } \\
\text { yang kurang dipahami pada dalam video } \\
\text { tersebut }\end{array}$ \\
$\begin{array}{l}\text { Video pembelajaran dapat digunakan } \\
\text { berkali-kali } \\
\text { Mudah di akses }\end{array}$ & \\
\hline
\end{tabular}

Table 3. Kelebihan dan kekurangan media whatsapp

\begin{tabular}{l}
\hline Kelebihan \\
\hline Pertanyaan dalam forum dapat langsung \\
direspon saat pembelajaran sehingga \\
lebih efektif dan mudah dipahami oleh \\
pembelajar
\end{tabular}

Pembelajar lebih aktif menyelesaikan soal-soal latihan

Materi yang diberikan baik berupa slide power point, video maupun dalam bentuk catatan langsung dapat dibuka di WA Group

Pelajar bisa saling berdiskusi dengan teman lain jika ada soal-soal yang belum terselesaikan dan belum dijawab dosen Lebih hemat quota

Materi dan bahan diskusi bisa disave langsung oleh pelajar sehingga mereka bisa menyelesaikan soal-soal latihan sambil mengulang dan membaca materi. 
D. Hasiru, dkk | Media-Media Pembelajaran Efektif dalam Membantu Pembelajaran ...

Table 4. Kelebihan dan kekurangan media zoom

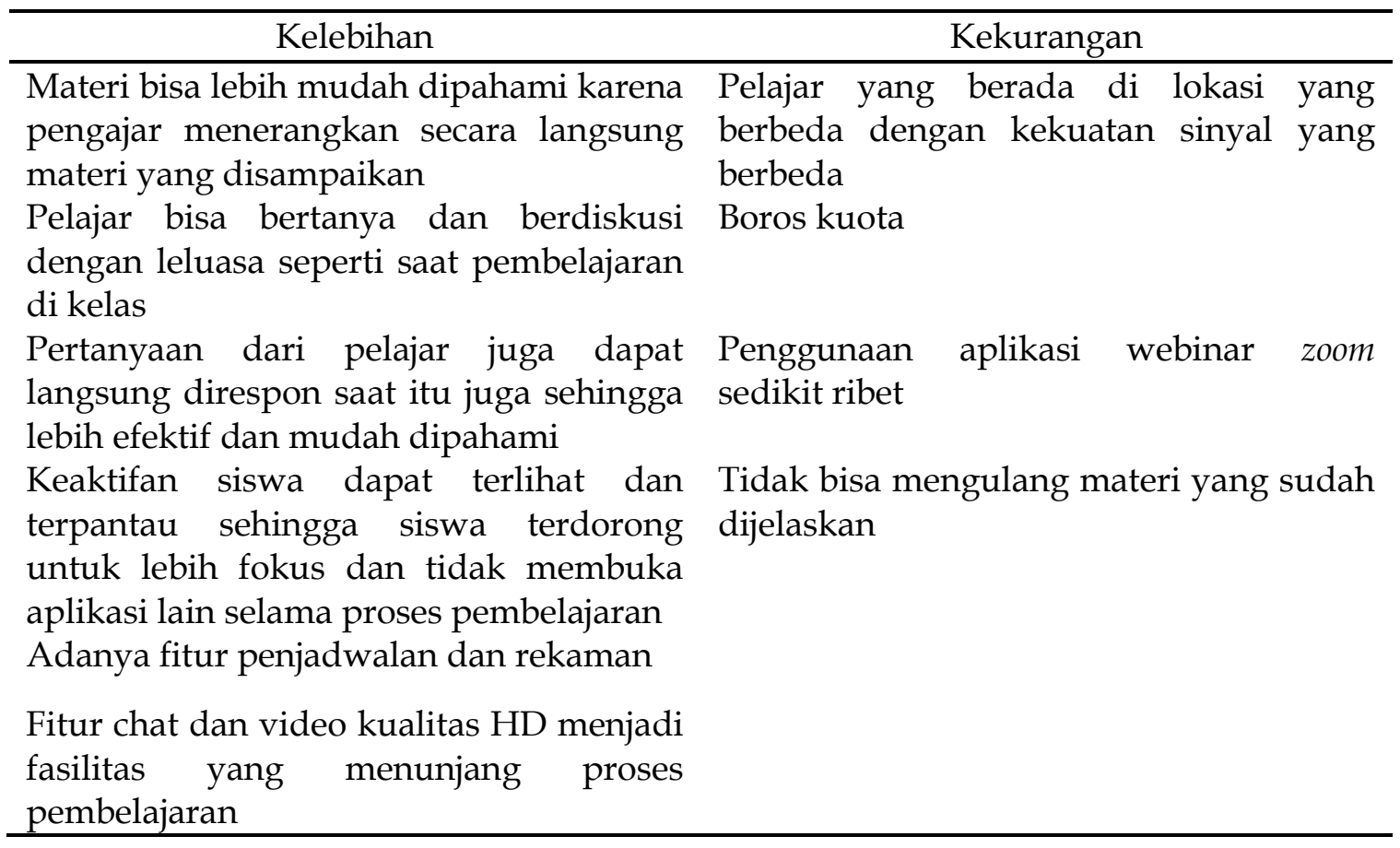

\section{Kesimpulan}

Media pembelajaran yang dapat dimanfaatkan dalam membantu pembelajaran matematika jarak jauh adalah google classroom, video pembelajaran, aplikasi chat whatsapp, dan Zoom. Dari keempat media tersebut yang sudah terbukti efektif dan menjadi alternatif dalam membantu pemebelajran matematika jarak jauh adalah Google Classroom dan Video pembelajaran karena berdasarkan hasil temuan dan analisis berbagai literatur yang ditemukan media Google Classroom dan Video pembelajaran dapat memenuhi indikator media pembelajaran yang efektif yaitu dapat menciptakan motivasi belajar, meningkatkan hasil belajar, peserta didik mampu mengingat dan menerapkan pengetahuan yang diperoleh. Sedangkan untuk Whatsupp dan Zoom belum cukup efektif digunakan dalam proses pemebelajaran matematika jarak jauh karena belum dapat memenuhi indikator media yang efektif dan terdapat kekurangan dalam penggunaanya serta untuk dapat digunakan secara efektif memerlukan pengembangan sehingga dapat dijadikan sebagai alternatif media yang efektif dalam membantu pembelajaran matematika jarak jauh.

\section{Referensi}

[1] Y. Yuliyana, “Corona Virus Disease (covid-19)," Jurnal Welleness and Healthy Magazine., vol. 2, no. 1, pp. 187. 2020.

[2] R. N. Auliya, "Kecemasan matematika dan pemahaman matematis," Formatif: Jurnal Ilmiah Pendidikan MIPA., vol. 6, no. 1, pp. 12-22, 2016.

[3] R. Susilana and R. Cepy, Media Pembelajaran, Bandung: CV Wacana Prima, 2009. 
D. Hasiru, dkk | Media-Media Pembelajaran Efektif dalam Membantu Pembelajaran ...

[4] P. M. Ammy, "Analisis Motivasi Belajar Mahasiswa Menggunakan Video Pembelajaran Sebagai Alternatif Pembelajaran Jarak Jauh (PJJ)," Jurnal Mathematic Paedogogic., vol. 5, no. 1, pp. 27-35, 2020.

[5] A. W. Abdullah, D. R. Isa, and N. F. Podungge, "Analisis Hasil Balajar Matematika Siswa pada Meteri Matriks melalui Pembelajaran Berbasis ELearning," Euler J. Ilm. Mat. Sains dan Teknol., vol. 9, no. 1, pp. 1-5, Apr. 2021, doi: 10.34312/euler.v9i1.10325.

[6] I. I. F. Shodiq and H. S. Zainiyati, "Pemanfaatan Media Pembelajaran E-learning Meggunakan Whatsapp sebagai Solusi Ditengah Penyebaran Covid-19 di MI Nurulhuda Jelu," Al-Insyiroh: Jurnal Studi Keislaman., vol. 6, no. 2, pp. 144-159, 2020.

[7] R. D. Sasanti, "Pengajuan Masalah Berbantuan Edmodo Sebagai Upaya Meningkatkan Keaktifan Siswa di Era Pandemi Covid-19," Euler J. Ilm. Mat. Sains dan Teknol., vol. 8, no. 2, pp. 60-69, Dec. 2020, doi: 10.34312/euler.v8i2.10417.

[8] S. K. Bulukaya, Y. Ismail, and S. Zakiyah, "Pengembangan Pembelajaran Berbasis Web pada Materi Tingkat Bunga Sederhana dan Tingkat Bunga Majemuk," Euler J. Ilm. Mat. Sains dan Teknol., vol. 8, no. 2, pp. 70-82, Dec. 2020, doi: 10.34312/euler.v8i2.10426.

[9] S. A. Hapsari and H. Pamungkas, "Pemanfaatan Google Classroom sebagai Media Pembelajaran Online di Universitas Dian Nuswantoro," WACANA: Jurnal Ilmiah Ilmu Komunikasi., vol. 18, no. 2, pp. 225-233, 2019.

[10] J. Monica and D. Fitriawati, "Efektivitas Penggunaan Aplikasi Zoom sebagai Media Pembelajaran Online Pada Mahasiswa Saat Pandemi Covid-19," Jurnal Ilmu Komunikasi., vol. 9, no. 2, pp. 1630-1640, 2020.

[11] M. Mustakim, "Efektivitas Pembelajaran Daring Menggunakan Media Online Selama Pandemi Covid-19 Pada Mata Pelajaran Matematika," Al-Asma: Jurnal of Islamic Education., vol. 2, no. 1, pp. 1-12, 2020.

[12] A. N. Muthy and H. Pujiastuti, "Analisis Media Pembelajaran E-Learning melalui Pemanfaatan Teknologi dalam Pembelajaran Matematika di Rumah sebagai dampak 2019-nCoV," Jurnal Math Educator Nusantara: Wahana Publikasi Karya Tulis Ilmiah Di Bidang Pendidikan Matematika., vol. 6, no. 1, pp. 94-103, 2020.

[13] T. T. Wijaya, "How Chinese Students Learn Mathematics During The Coronavirus Pandemic," IJERI: International Journal of Educational Research and Innovation., vol. 15, pp. 1-16, 2021.

[14] R. Husna, "Efektivitas Pembelajaran Turunan pada Masa Pandemi Covid-19 Melalui Media Mobile Learning Ditinjau dari Hasil Belajar Mahasiswa," Numeracy., vol. 7, no. 2, pp. 324-333, 2020.

[15] R. A. Apsari, S. Sripatmi, M. A. Maulyda, and N. H. Salsabila, "Pembelajaran Matematika Dengan Media Obrolan Kelompok Multi-Arah Sebagai Alternatif Kelas Jarak Jauh," Jurnal Elemen., vol. 6, no. 2, pp. 318-332, 2020.

[16] D. Padmo, and B. Pribadi, "Media dalam Pendidikan terbuka jarak jauh," Setij adi Ma.,pp. 36, 2002. 
D. Hasiru, dkk | Media-Media Pembelajaran Efektif dalam Membantu Pembelajaran ...

[17] P. Mudamayanti, "Efektivitas Penggunaan Aplikasi Google Classroom untuk Mengukur Pencapaian Indikator Terhadap Pembelajaran Matematika Materi Pengolahan Data Kelas V Sd di Tengah Situasi Lockdown Akibat Virus Covid19," Jurnal Penelitian Pendidikan Guru Sekolah Dasar., vol. 8, no. 3, 2020.

[18] Y. Darmawan, "Penggunaan Aplikasi Google Classroom dalam Upaya Meningkatkan Hasil Belajar Matematika pada Siswa Kelas X IPS 3 SMA Batik 2 Surakarta," Universitas Muhammadiyah Surakarta, Surakarta, 2019.

[19] H. H. Batubara, Media Pembelajaran Efektif, Semarang: Fatwa Publishing, 2020.

[20] E. Susanti and M. Halima, "Desain Video Pembelajaran yang Efektif pada Pendidikan Jarak Jauh Studi di Universitas Terbuka," Jurnal Pendidikan dan Kebudayaan., vol. 3, no. 2, pp. 167-185, 2018.

[21] F.P.P. Krisna and M. H. P. Marga, "Pemanfaatan Video untuk Pembelajaran Matematika Berbasis Masalah Kontekstual pada Topik Aljabar," Prosiding Seminar Nasional Pendidikan Mtematika Etnomatnesia. 2018.

[22] E. Nurdin, A. Ma'aruf, Z. Amir, R. Risnawati, N. Noviarni, and M. P. Azmi, "Pemanfaatan Video Pembelajaran Berbasis Geogebra untuk meningkatkan Kemampuan Pemahaman Konsep Matematis Siswa SMK," Jurnal Riset Pendidikan Matematika., vol. 6, no. 1, pp. 87-98, 2019.

[23] I. Baharuddin, "Efektivitas Penggunaan Media Video Tutorial sebagai Pendukung Pembelajaran Matematika terhadap Minat dan Hasil Belajar Peserta Didik SMA Negeri 1 Bajo Kabupaten Luwu Sulawesi Selatan," Jurnal Nalar Pendidikan., vol. 2, no. 2, 2014.

[24] B. Choki, "The Effectiveness of Whatsapp Mobile Learning Activities Guided by Activity Theory on Students Knowledge Mangement," Contemporary Educational Technology., vol. 6, no. 3, pp. 221-238, 2015.

[25] N. A. Yensy, "Efektifitas Pembelajaran Statistika Matematika Melalui Media Whatsapp Group Ditinjau dari Hasil Belajar Mahasiswa (Masa Pandemik Covid 19)," Jurnal Pendidikan Matematika Raflesia., vol. 6, no. 2, pp. 65-74, 2020.

[26] H. Kiayimodjo, "Analisis Hasil Belajar Matematika Siswa Dalam Pembelajaran Daring Dengan Menggunakan Media Whatsapp sebagai Sarana Pembelajaran di MTs Negeri 1 Bolaang Mongondow Timur," Universitas Negeri Gorontalo, 2020.

[27] J. W. Kusuma, and H. Hamidah, "Perbandingan Hasil Belajar Matematika Dengan Penggunaan Platform Whatsapp Group dan Webinar Zoom dalam Pembelajaran Jarak Jauh pada Masa Pandemik Covid 19," JIPMat, vol. 5, no. 1, 2020. 